Vol. 1 Nomor 2

Tahun 2021

Hal. $99-103$

\title{
HUBUNGAN ANTARA KONTRASEPSI DMPA (DEPO MEDROXY PROGESTERON ASETAT) DENGAN PENINGKATAN BERAT BADAN AKSEPTOR KB DI PUSKESMAS PUNGGUR TAHUN 2018
}

\author{
Weda Ayu Ardini 1)
}

\begin{abstract}
ABSTRAK
Jumlah Populasi di Indonesia semakin meningkat, hal ini menjadi masalah besar. Indonesia merupakan negara ke 5 di dunia dengan estimasi jumlah penduduk terbanyak yaitu 249 juta jiwa, dengan Angka Fertilitas atau Total Fertility Rate (TFR) 2,6 masih tinggi dibandingkan dengan negara-negara di ASEAN lainnya dengan angka rata-rata 2,4 (Kemenkes RI, 2014). Upaya menangani laju penduduk Indonesia mengadakan program Keluarga Berencana untuk tercapai keluarga berkualitas yaitu dengan mengatur jumlah anak, adapun alat kontrasepsi yang banyak digunakan adalah Suntik DMPA, Efek samping kontrasepsi suntik DMPA yang paling tinggi frekuensinya yaitu peningkatan berat badan yang dapat berakibat akseptor drop out. Tujuan penelitian ini untuk mengetahui hubungan antara kontrasepsi DMPA (Depo Medroxy Progesteron Asetat) dengan peningkatan berat badan pada Akseptor KB di Puskesmas Punggur tahun 2018.

Hasil dari penelitian yang dilakukan oleh peneliti terhadap 133 responden bahwa terdapat 77 akseptor KB (57,8 \%) menggunakan suntik KB DMPA, dan 73 akseptor $(45,1 \%)$ akseptor KB di Puskesmas Punggur mengalami peningkatan berat badan selama satu tahun setelah menggunakan alat kontrasepsi. Berdasarkan uji bivariate akseptor dengan kontrasepsi Suntik DMPA dan mengalami peningkatan berat badan sebanyak 43 $(55,8 \%)$ akseptor KB. Berdasarkan hasil analisis chi-square dengan tingkat kepercayaan $95 \%$ diperoleh nilai $p$ value $=0,004<\alpha(0,05)$, maka Ha diterima dan Ho ditolak atau berarti ada hubungan antara Suntik DMPA dengan peningkatan berat badan askseptor KB di Puskesmas Punggur tahun 2018 dan Nilai Odds Ratio (OR) sebesar 2,9.

Diharapkan bagi tenaga kesehatan untuk meningkatkan pelayanan Keluarga Berencana khususnya dalam hal pemakaian kontrasepsi DMPA. Serta diharapkan bagi calon akseptor KB meningkatkan pengetahuannya terutama mengenai alat kontrasepsi yang akan dipilih sehingga dapat meminimalisir jika terjadi efek pemakaian alat kontasepsi dan berperan dalam program nasional keluarga berencana yaitu sebagai akseptor KB Aktif.
\end{abstract}

Kata Kunci : Kontrasepsi DMPA, Berat Badan

The number of population in Indonesia is increasing, this is a big problem. Indonesia is the fifth country in the world with the highest estimated population of 249 million, with 2.6 Fertility or Total Fertility Rate (TFR) still high compared to other ASEAN countries with an average rate of 2.4 (Ministry of Health RI, 2014). Efforts to deal with the rate of Indonesian population hold a Family Planning program to achieve quality families, namely by regulating the number of children, while the most widely used contraceptives are DMPA injections, the most frequent side effect of DMPA injection contraception is weight gain which can result in drop out acceptors. The purpose of this study was to determine the relationship between DMPA (Depo Medroxy Progesteron Asetat) contraception and weight gain in KB acceptors at Punggur Health Center in 2018.

The results of the research conducted by researchers on 133 respondents that there were 77 family planning acceptors (57.8\%) using DMPA KB injections, and 73 acceptors (45.1\%) KB acceptors at Purbolinggo Health Center experienced a one-year increase in weight after using the tool contraception. Based on the bivariate test of acceptors with DMPA injection contraception and weight gain of 43 (55.8\%) KB acceptors. Based on the results of the chi-square analysis with a 95\% confidence level obtained p-value $=0.004<\alpha(0.05)$, then Ha is accepted and Ho is rejected or means there is a relationship between DMPA injections with an increase in birth control weight gain in Punggur Health Center in 2018 and the Odds Ratio (OR) is 2.9.

It is expected that health workers to improve family planning services, especially in the case of DMPA contraceptive use. And it is expected that KB acceptors will increase their knowledge, especially regarding contraceptives to be chosen so that they can minimize the effects of contraceptive device use and play a role in the national family planning program, namely Active KB acceptors.

Keywords: DMPA Contraception, Body Weight 
e-ISSN 2774-4671

Vol. 1 Nomor 2

Tahun 2021

Hal. 99 - 103

\section{JURNAL ILMIAH KEBIDANAN}

\section{PENDAHULUAN}

\section{METODE}

Jenis penelitian survey analitik dengan rancangan cross sectional, bertempat di Puskesmas Punggur tahun 2019, dilaksanakan Januari-Februari 2018. Populasi adalah Akseptor KB di Puskesmas Punggur tahun 2018 sejumlah 199 akseptor, Pengambilan sampel menggunakan Purposive sampling, dengan jumlah 133 responden. Hasil penelitian diolah dengan tahapan editing, scoring, coding,entering, dan cleaning. Sedangkan untuk membuktikan hipotesis menggunakan uji Univariate dan Bivariate dengan derajat kemaknaan $95 \%$.

\section{HASIL DAN PEMBAHASAN \\ Distribusi Variabel}

Berdasarkan Tabel 1, dapat dijelaskan bahwa dari seluruh responden terdapat $57,8 \%$, dan terdapat $45,1 \%$ responden yang mengalami penambahan berat badan $>/=3 \mathrm{~kg}$.

Tabel 1

Distribusi Variabel Hasil Penelitian pada akseptor KB di Puskes mas Punggur Tahun 2018

\begin{tabular}{|c|c|c|}
\hline Variabel & Jumlah & $\%$ \\
\hline \multicolumn{3}{|l|}{ Jenis ALKON } \\
\hline - Suntik DMPA & 77 & 57,8 \\
\hline - $\quad$ ALKON lain & 56 & 42,2 \\
\hline \multicolumn{3}{|l|}{ Berat Badan Responden } \\
\hline - Tidak naik & 73 & 54,9 \\
\hline - $\quad$ Naik $>/=3 \mathrm{~kg}$ & 60 & 45,1 \\
\hline
\end{tabular}

Uji Bivariat

Hubungan usia dengan kejadian anemia

Tabel 2

Hubungan Antara Kontrasepsi DMPA (Depo Medroxy Progesteron Asetat) Dengan Peningkatan Berat Badan Akseptor KB Di Puskesmas Punggur Tahun 2018

\begin{tabular}{|c|c|c|c|c|c|c|c|c|}
\hline \multirow{3}{*}{$\begin{array}{c}\text { KB } \\
\text { Suntik } \\
\text { DMPA }\end{array}$} & \multicolumn{4}{|c|}{ Peningkatan Berat Badan } & \multirow{2}{*}{\multicolumn{2}{|c|}{ Jumlah }} & \multirow{3}{*}{$\begin{array}{c}p- \\
\text { value }\end{array}$} & \multirow{3}{*}{$\begin{array}{c}\text { OR } \\
\text { CI : } 95 \%\end{array}$} \\
\hline & \multicolumn{2}{|c|}{ Ya } & \multicolumn{2}{|c|}{ Tidak } & & & & \\
\hline & $\mathrm{N}$ & $\%$ & $\mathrm{~N}$ & $\%$ & $\mathrm{~N}$ & $\%$ & & \\
\hline Ya & 43 & 55,8 & 34 & 44,2 & 77 & 100 & 0,004 & 2,9 \\
\hline Tidak & 17 & 30,4 & 39 & 69,6 & 56 & 100 & & \\
\hline Jumlah & 60 & 45,1 & 73 & $\overline{54,9}$ & 133 & $\overline{100}$ & & \\
\hline
\end{tabular}


Berdasarkan tabel 2, dari 133 akseptor $\mathrm{KB}$ yang menggunakan alat kontrasepsi Suntik DMPA dan mengalami peningkatan berat badan sebanyak 43 akseptor $(55,8 \%)$. Berdasarkan hasil analisis chi-square dengan tingkat kepercayaan $95 \%$ diperoleh nilai $\mathrm{p}$-value $=0,004<\alpha(0,05)$, maka $\mathrm{Ha}$ diterima dan Ho ditolak atau berarti ada hubungan antara Suntik DMPA dengan peningkatan berat badan askseptor $\mathrm{KB}$ di Puskesmas Punggur tahun 2018 dan Nilai Odds Ratio (OR) sebesar 2,9.

Hal ini sesuai dengan penelitian yang dilakukan oleh penelitian yang dilakukan oleh Pratiwi, dkk., 2014 bahwa Terdapat hubungan yang bermakna antara penggunaan kontrasepsi hormonal suntik DMPA dengan peningkatan berat badan di Puskesmas Lapai Kota Padang (2015) bahwa terdapat Hubungan Kontrasepsi Suntik Dengan Peningkatan Berat Badan Akseptor (Studi Di Bps Dwenti K.R. Desa Sumberejo Kabupaten Lamongan tahun 2015 dengan nilai $p=0,049$.

Efek samping kontrasepsi suntik yang paling tinggi frekuensinya yaitu peningkatan berat badan. Peningkatan berat badan $3 \mathrm{~kg}$ selama tahun pertama dan bertambah secara progresif selama tahun ke dua (Runjati dan Umar S., 2017). Menurut Bahamondes (2001) Kenaikan berat badan dikaitkan dengan DMPA (Depo Medroxy Progesteron Asetat) (Williams, 2012).

Penyebab pertambahan berat badan mengarah pada hipotesa para ahli bahwa DMPA (Depo Medroxy Progesteron Asetat) merangsang pusat pengendali nafsu makan di hypothalamus, yang menyebabkan akseptor makan lebih daripada biasanya. Untuk mendapatkan gambaran nyata tentang kejadian peningkatan berat badan yang dialami akseptor kontrasepsi suntik maka perlu dilakukan suatu penelitian untuk mengetahui sejauh mana pengaruh kontrasepsi suntik dengan peningkatan berat badan seksual (Runjati dan Umar S., 2017). Beberapa penyakit atau masalah kesehatan akibat kelebihan berat badan yaitu: masalah persendian, gagal jantung, diabetes mellitus dan gangguan hormonal (Haryani, dkk., 2010). Menurut Rocky (2008) bahwa Obesitas adalah kelebihan berat badan sebagai akibat dari penimbunan lemak tubuh yang berlebihan. Setiap orang memerlukan sejumlah lemak tubuh untuk menyimpan energi, sebagai penyekat panas, penyerap guncangan dan fungsi lainnya (Anggraini, dkk., 2015).

Dampak kelebihan berat badan atau obesitas pada tubuh wanita yaitu berdasarkan hasil penelitian yang dilakukan oleh Anggraini, dkk., (2015) bahwa ada hubungan antara obesitas dengan infertilitas pada wanita Usia subur Di Rumah Sakit Awal Bross Pekanbaru tahun 2014 dengan $\mathrm{x}^{2}$ hitung $16.07>$ dari $\mathrm{x}^{2}$ table 3.84.

Menurut penulis diharapkan kepada tenaga kesehatan yang memberikan pelayanan suntik KB DMPA (Depo Medroxy Progesteron Asetat) untuk memberikan sosialisasi tentang kelebihan dan kekurangan menggunakan suntik DMPA (Depo Medroxy Progesteron Asetat) dan melakukan observasi setiap kali kunjungan untuk memantau berat badan sehingga tidak terjadi obesitas pada ibu pengguna akseptor KB DMPA serta diharapkan akseptor dapat memahami dan menerapkan hasil sosialisasi oleh tenaga kesehatan. 
Vol. 1 Nomor 2

Tahun 2021

Hal. $99-103$

\section{KESIMPULAN DAN SARAN}

\section{A. Kesimpulan}

1. Distribusi frekuensi alat kontrasepsi yang digunakan akseptor yang mengalami peningkatan berat badan di Puskesmas Purbolinggo tahun 2019 dari 133 akseptor KB sebanyak 77 akseptor $\mathrm{KB}(57,8 \%)$ yang memilih menggunakan alat kontrasepsi suntik KB DMPA.

2. Distribusi frekuensi peningkatan berat badan akseptor $\mathrm{KB}$ yang mengalami peningkatan berat badan di Puskesmas Purbolinggo tahun

\section{B. Saran}

Berdasarkan hasil penelitian dan kesimpulan, maka disarankan :

\section{Bagi Responden (Akseptor KB)}

Diharapkan untuk seluruh calon akseptor KB dapat meningkatkan pengetahuannya terutama mengenai alat kontrasepsi yang akan dipilih sehingga dapat meminimalisir jika terjadi efek pemakaian alat kontasepsi yang dipilih tersebut dan dapat mendiskusikan bersama dengan suami. Serta berperan dalam program nasional keluarga berencana yaitu sebagai akseptor $\mathrm{KB}$ Aktif.

2. Bagi Petugas Kesehatan di Puskesmas Punggur

\section{DAFTAR PUSTAKA}

Anggraini, dkk., 2015. Pengaruh Obesitas Terhadap Infertilitas Pada Wanita Pasangan Usia Subur Di Rumah Sakit Awal Bros Pekanbaru tahun 2014. Jurnal Proteksi Kesehatan, Volume 4, Nomor 1, April 2015 hlm 49-58. Diakses pada 12 Februari 2019

2018 dari 133 akseptor terdapat 60 akseptor $(45,1 \%)$ yang tidak mengalami peningkatan berat badan selama satu tahun setelah menggunakan alat kontrasepsi.

3. Terdapat hubungan antara kontrasepsi suntik DMPA dengan peningkatan berat badan pada Akseptor KB di Puskesmas Punggur tahun 2018 dengan hasil nilai $P$ value $=0.004<$ nilai $\alpha=0.05$.

Diharapkan bagi pihak Puskesmas Purbolinggo khususnya tenaga kesehatan seperti bidan, perawat dan bagian promosi kesehatan, diharapkan dapat meningkatkan pelayanan kebidanan yang terkait dengan pelayanan Keluarga Berencana khususnya dalam hal pemakaian kontrasepsi DMPA.

\section{Bagi Peneliti Selanjutnya}

Diharapkan hasil penelitian ini dapat digunakan untuk penelitian lebih lanjut baik mengenai besar sampel maupun faktorfaktor lain yang mempengaruhi peningkatan berat badan pada akseptor KB DMPA.

Arikunto, 2010. Prosedur Penelitian Suatu Pendekatan Praktik. Rineka Cipta. Jakarta

Cuningham, 2012. Obstetri Williams Edisi 23. EGC. Jakarta

Dhania Pratiwi, Syahredi, Erkadius, 2014. Hubungan Antara Penggunaan Kontrasepsi Hormonal Suntik DMPA Dengan Peningkatan Berat Badan Di Puskesmas Lapai Kota Padang 
Vol. 1 Nomor 2

Tahun 2021

Hal. $99-103$

http://jurnal.fk.unand.ac.id. diakses pada tanggal 17 Desember 2018

Ekawati, 2010. Pengaruh KB Suntik Dmpa

Terhadap PeningkatanBerat Badan Di

Bps Siti SyamsiyahWonokarto

Wonogiri Diakses pada tanggal 15 Desember 2018

Fitrianingsih, 2015. Hubungan

Penggunaan Kontrasepsi Suntik Dmpa

Dengan Kejadian Peningkatan Berat

Badan Dan Upaya Penanganannya.

Diakses pada tanggal 15 Desember 2018.

Ida Susila dan Oktaviani, 2015.Hubungan

Kontrasepsi Suntik Dengan

Peningkatan Berat Badan Akseptor

(Studi Di Bps Dwenti K.R. Desa

Sumberejo Kabupaten Lamongan

2015) diakses pada tanggal 15

Desember 2018.

Haryani dkk. 2010., Pengaruh frekuensi kontrasepsi suntik DMPA dengan kejadian peningkatan berat badan pada Akseptor KB DMPA di BPS Dian Yuni Purwani Desa klahang Kecamatan Sokaraja Kabupaten Banyumas. diakses pada tanggal 15 Desember 2018.

Isnaini, 2010. Hubungan Lama Pemakaian Dmpa Dengan PeningkatanBerat Badan Akseptor Suntik Di Bps SuhandriyahKedon

SumbermulyoBantul. Diakses pada tanggal 15 Desember 2018.

Kemenkes RI, 2011. Pedoman Pelaksanaan Kelas Ibu Hamil. Jakarta

Kemenkes RI, 2014. Profil Kesehatan Indonesia tahun 2013. Departemen Kesehatan RI. Jakarta

Notoatmojo.S, 2012. Metode Penelitian Kesehatan. Rineka Cipta. Jakarta

Prawirohardjo, S dan Wiknjosatro, H., 2014. Ilmu Kebidanan. PT Bina Pustaka Sarwono Prawiroharjo. Jakarta

Rahmawati, 2012. Hubungan Lama Pemakaian KB Suntik DMPA Dengan
Peningkatan Berat Badan Pada Akseptor Di Puskesmas Mergansan Yogyakarta Tahun 2012. Diakses pada tanggal 15 Desember 2018

Riyadi, 2013. Mengukuir Status Gizi dengan Indeks Massa Tubuh. https://hadiriyadi.blogspot.com/2013

/01/mengukur-status-gizi-dengan indeks.html. Diakses pada tanggal 17 Desember 2018

Novita, N. Dan Franciska, Y., 2011. Promosi Kesehatan Dalam Pelayanan Kebidanan. Salemba Medika. Jakarta

Profil Kesehatan Lampung tahun 2012. 2013. Dinas Kesehataa Provinsi Lampung. Bandar Lampung

Indofatin. Pusat Data dan Informai Kementrian Kesehataan RI. 2013. Jakarta

Purwoastuti dan Walyani, 2015. Panduan materi kesehatan Reproduksi dan Keluarga Berencana. Pustaka Baru Press. Yogyakarta.

Runjiati dan Syahniar. 2017. Teori dan Asuhan Kebidanan. EGC. 2018

Sulistiyaningsih, 2017. Hubungan Lama Penggunaan KB Suntik DMPA Dengan Peningkatan Berat Badan Pada Akseptor KB Di Klinik Pratama Lestari Wedarijaksa Pati. Jurnal Kebidanan Dan Kesehatan (Journal Of Midwifery And Health) Vol. 7, No. 1 ISSN : 2088-4109 Diakses Pada Tanggal 15 Desember 2018 